\title{
Anemia pada Sindrom Nefrotik Anak: Patogenesis dan Tata Laksana
}

\author{
Sudung O. Pardede \\ Departemen Ilmu Kesehatan Anak Fakultas Kedokteran Universitas Indonesia-Rumah Sakit Dr. Cipto Mangunkusumo, Jakarta
}

Sindrom nefrotik merupakan penyakit ginjal yang sering pada anak, ditandai dengan proteinuria masif, hipoalbuminemia, edema, dan hiperkolesterolemia. Sindrom nefrotik dapat menyebabkan komplikasi hipovolemia, renjatan, gangguan ginjal akut, infeksi, tromboembolisme, gangguan elektrolit, gangguan endokrin, dan anemia. Komplikasi ini disebabkan hilangnya protein melalui urin, seperti albumin, faktor koagulasi, imunoglobulin, hormone-binding protein, transferin, dan eritropoietin. Anemia pada sindrom nefrotik dapat disebabkan perubahan homeostasis besi dan transferin, pengeluaran eritropoietin melalui urin, defisiensi vitamin B12, serta peran obat dan logam. Ekskresi besi dan transferin melalui urin menyebabkan kadar transferin plasma menurun yang mengakibatkan penurunan kadar besi plasma dan anemia mikrositik hipokrom. Kehilangan erItropoietin melalui urin menyebabkan anemia defisiensi eritropoietin. Kehilangan transkobalamin dan vitamin B12 melalui urin menurunkan kadar vitamin B12 plasma. Kehilangan seruloplasmin melalui urin dapat menyebabkan defisiensi tembaga yang mengakibatkan anemia. Obat angiotensin converting enzyme inhibitors ( $A C E I s$ ) dapat menyebabkan anemia dengan mekanisme inhibisi eritropoiesis dengan menurunkan kadar eritropoietin sirkulasi. Keberhasilan terapi anemia pada sinrom nefrotik bergantung pada penyebab anemia. Anemia defisiensi besi diterapi dengan suplementasi besi. Pemberian eritropoietin rekombinan efektif dan aman dalam tata laksana anemia pada sindrom nefrotik. Defisiensi vitamin B12 diterapi dengan vitamin B12 dan anemia defisiensi tembaga diterapi dengan suplementasi tembaga glukonat. Sari Pediatri 2020;22(1):57-64

Kata kunci: anemia defisiensi, eritropoietin, ferritin, sindrom nefrotik

\section{Anemia in Children with Nephrotic Syndrome: Pathogenesis and Management}

Sudung O. Pardede

Nephrotic syndrome is a common kidney disease in children, consisted of massive proteinuria, hypoalbuminemia, edema, and hypercholesterolemia. Some of nephrotic syndrome complications are hypovolemia, shock, acute kidney injury, infections, thromboembolism, electrolyte disturbances, endocrine disorders, and anemia. These complications occurred due to loss of protein in urine, including albumin, coagulation factors, immunoglobulins, hormone binding proteins, transferrin, erythropoietin. Anemia in nephrotic syndrome may be caused by altered iron and transferrin homeostasis, loss of erythropoietin in urine, the role of metal and drugs, and vitamin B12 deficiency. Urinary loss of iron and transferrin is accompanied by low serum transferrin and iron levels which cause hypochromic microcytic anemia. Urinary loss of erythropoietin in nephrotic syndrome will cause erythropoietin deficiency anemia. Losses of transcobalamin and vitamin B12 in the urine will decrease serum level of vitamin B12. Urinary losses of ceruloplasmin can lead to copper deficiency and cause anemia. Angiotensin converting enzyme inhibitors (ACEIs) is known to be associated with the development of anemia because ACEi have inhibitory effects on erythropoiesis by lowering circulating erythropoietin level. Successful treatment of anemia in nephrotic syndrome depends on the underlying causes of anemia. Iron deficiency anemia should be treated with iron supplementation. Efficacy and safety of recombinant human erythropoietin in the treatment of anemia in nephrotic syndrome is well established. Vitamin B12 deficiency can be treated with vitamin B12 and copper deficiency anemia should be treated by supplementation with copper gluconate. Sari Pediatri 2020;22(1):57-64

Keywods: deficiency anemia, erythropoietin, ferritin, nephrotic syndrome

Alamat korespondensi: Sudung O. Pardede. Departemen Ilmu Kesehatan Anak Fakultas Kedokteran Universitas Indonesia-RSCM, Jakarta. Email: suopard@yahoo.com 
S indrom nefrotik merupakan penyakit ginjal yang sering pada anak. Sindrom ini terdiri atas proteinuria masif, hipoalbuminemia $(<$ $2,5 \mathrm{~g} / \mathrm{dL}$ ), edema, dan hiperkolesterolemia. Terapi utama sindrom nefrotik adalah kortikosteroid, yaitu prednison dosis penuh (full dose) $60 \mathrm{mg} / \mathrm{m}^{2} \mathrm{LPB} /$ hari selama 4 minggu dilanjutkan dengan prednison dosis $2 / 3$ nya $\left(40 \mathrm{mg} / \mathrm{m}^{2} \mathrm{LPB} /\right.$ hari) tiga hari berturutturut dalam seminggu (intermitten) atau selang hari (alternating) selama 4 minggu. ${ }^{1-3}$ Secara etiologi, sindrom nefrotik dibedakan menjadi sindrom nefrotik kongenital, primer, dan sekunder. Secara klinis sindrom nefrotik dibagi berdasarkan respon terhadap steroid menjadi sindrom nefrotik responsif steroid, sindrom nefrotik relaps jarang, sindrom nefrotik relaps sering dan dependen steroid, serta sindrom nefrotik resisten steroid. Pada sindrom nefrotik relaps sering dan dependen steroid, serta sindrom nefrotik resisten steroid, selain steroid diberikan juga imunosupresan lain seperti siklofosfamid, klorambusil, siklosporin, mikofenolat mofetil, takrolimus, rituximab, atau pun levamisol. ${ }^{1-3}$

Berbagai komplikasi dapat terjadi pada sindrom nefrotik karena penyakitnya sendiri atau akibat pemberian obat. Komplikasi pada sindrom nefrotik antara lain hipovolemia, renjatan, gangguan ginjal akut, infeksi, tromboembolisme, gangguan elektrolit, gangguan endokrin, anemia, malnutrisi, dan pertumbuhan terlambat. ${ }^{1-3}$ Berbagai komplikasi ini umumnya disebabkan karena hilangnya berbagai protein melalui urin, seperti albumin, faktor koagulasi, imunoglobulin, hormone-protein binding, transferin, eritropoietin. ${ }^{4}$ Selain albuminuria terjadi juga ekskresi protein plasma berukuran intermediate seperti transferin dan vitamin D-binding protein serta pengeluaran elektrolit atau mikronutrien sehingga terjadi perubahan kadarnya dalam plasma. ${ }^{5}$

Meskipun anemia merupakan salah satu komplikasi sindrom nefrotik, tetapi anemia sebagai komplikasi sindrom nefrotik tidak sering dibicarakan dan laporan prevalensi anemia pada sindrom nefrotik sangat terbatas. Feinstein dkk melaporkan kejadian anemia pada sindrom nefrotik sebesar 59\%. ${ }^{6}$ Iorember dan Aviles (2017) melaporkan 28\% pasien mengalami anemia selama perjalanan penyakitnya. ${ }^{7}$

\section{Patogenesis sindrom nefrotik}

Sindrom nefrotik terjadi karena disfungsi limfosit $\mathrm{T}$ sistemik yang mengeluarkan sitokin toksik terhadap membran basalis glomerulus, ${ }^{8,9}$ yaitu ketidakseimbangan sel $\mathrm{T}$ helper dan sel $\mathrm{T}$ regulator. Sel $\mathrm{T}$ helper akan mengeluarkan faktor permeabilias vaskular yaitu sitokin proinflamasi yang akan menyebabkan perubahan muatan (charge) dan ukuran (size) pada membran basalis glomerulus yang meningkatkan permeabilitas dinding glomerulus sehingga terjadi proteinuria, ${ }^{10}$ sedangkan sel $\mathrm{T}$ regulator akan mengeluarkan sitokin antiinflamasi yang menghambat peran sitokin proinflamasi yang dikeluarkan sel $\mathrm{T}$ helper. ${ }^{11}$ Pada sindrom nefrotik idiopatik terdapat penurunan aktivasi sel $T$ regulator yang akan mengalami perbaikan fungsi pada saat remisi dan pemberian imunosupresan. Penelitian Araya $\mathrm{dkk}^{12}$ melaporkan penurunan sel $\mathrm{T}$ regulator pada sindrom nefrotik idiopatik relaps yang berbeda bermakna dibandingkan dengan anak sehat dan pada keadaan remisi. Penurunan mekanisme sel $\mathrm{T}$ regulator menyebabkan menurunnya pelepasan sitokin antinflamasi sehingga terjadi aktivasi sel $\mathrm{T}$ helper untuk mengeluarkan sitokin proinflamasi dan sitokin lainnya yang menyebabkan peningkatan permeabilitas glomerulus. ${ }^{12,13}$

Faktor permeabilitas vaskular yang utama adalah sitokin. Sitokin akan berinteraksi dengan dinding kapiler glomerulus melalui reseptor permukaan. Kompleks adhesi reseptor menimbulkan sinyal ke sitoskeletalaktin submembran sehingga terjadi berbagai perubahan intraselular, seperti rearrangements sitoskeletal. ${ }^{14,15}$ Perubahan muatan membran basalis glomerulus terjadi karena berkurangnya proteoglikan heparan sulfat dan asam sialat membran basalis glomerulus akibat meningkatnya katabolisme heparan sulfat membran basalis glomerulus. Hilangnya muatan negatif membran basalis glomerulus akan menimbulkan hilangnya reaksi penolakan antara membran basalis glomerulus dan protein plasma yang bermuatan negatif, yang berarti permeabilitas dinding membran basalis glomerulus meningkat dan terjadilah proteinuria.

Selain perubahan muatan membran basalis glomerulus, kelainan nefrin dan neph-1 sebagai komponen utama slit diafragma akan menyebabkan kelainan integritas slit diafragma juga akan menimbulkan proteinuria. Dengan demikian ada beberapa mekanis me terjadinya proteinuria: 1 . Pengurangan muatan anion membran basalis glomerulus yang akan meningkatkan pasase protein plasma yang bermuatan negatif melalui filter. ${ }^{16} 2$. Lepasnya foot processes podosit dari membran basalis glomerulus yang akan meningkatkan aliran plasma melewati membran basalis glomerulus tanpa foot processes. 3. Kelainan fungsional dan struktural 
pada komponen slit diafragma yang menyebabkan kebocoran protein melalui slit pore podosit, ${ }^{17}$ namun penyebab utama proteinuria adalah perubahan muatan anion membran basalis glomerulus. ${ }^{16}$

Secara sederhana, terjadinya proteinuria dapat digambarkan seperti pada Gambar 1, Faktor pencetus akan mengaktivasi limfosit $\mathrm{T}$ (langkah 1) untuk mengeluarkan faktor permeabilitas vaskular (vascular permeabilitas factor) (langkah 2) dan faktor permeabilitas vaskular akan meningkatkan permeabilitas glomerulus (langkah 3) sehingga albumin plasma keluar melalui dinding glomerulus (langkah 4). ${ }^{15}$

Selain disfungsi limfosit $\mathrm{T}$, limfosit $\mathrm{B}$ ikut berperan dalam patogenesis sindrom nefrotik. Pendapat ini didukung oleh penelitian tentang pemberian rituximab, yaitu antibodi monoklonal anti-CD20 yang dapat menyebabkan remisi pada sindrom nefrotik. Antibodi antimonoklonal menyebabkan deplesi sel B. ${ }^{18}$ Peran sel B dalam patogenesis sindrom nefrotik idiopatik didukung oleh meningkatnya produksi nitric oxide oleh sel B selama relaps. Jumlah nitric oxide yang diproduksi oleh limfosit B serum lebih tinggi pada pasien sindrom nefrotik idiopatik relaps dibandingkan dengan pada pasien dengan penyakit ginjal lainnya dan anak sehat. ${ }^{9}$

Perubahan ukuran dan muatan membran basalis glomerulus menyebabkan peningkatan permeabilitas glomerulus yang mengakibatkan proteinuria. Protein yang keluar melalui urin terlihat pada Tabel 1.

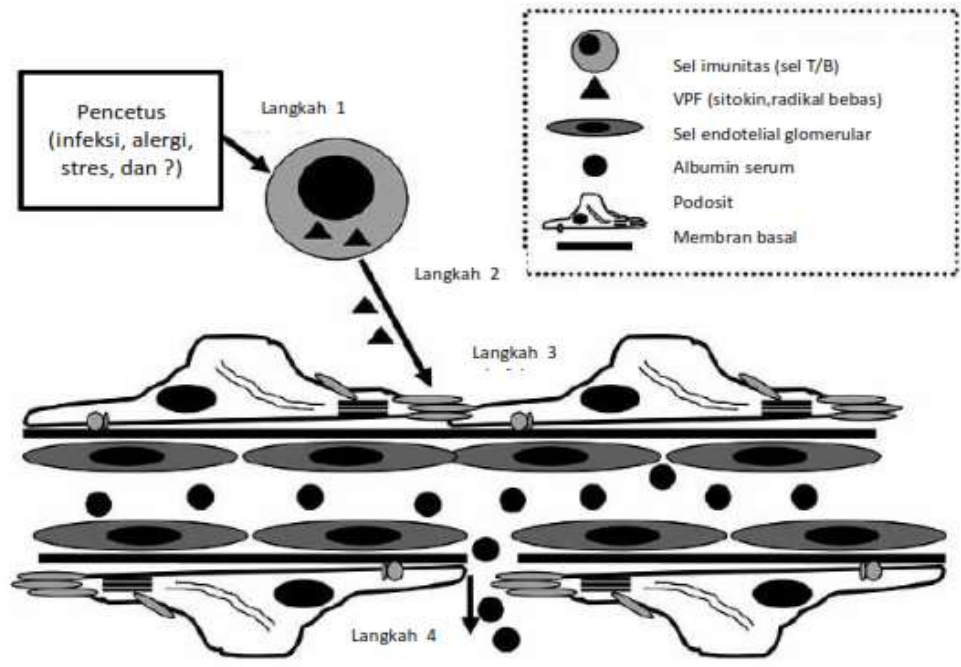

Gambar 1: Mekanisme proteinuria pada sindrom nefrotik idiopatik ${ }^{15}$ (Modifikasi dari Kaneko, 2009)

Tabel 1. Protein dan substansia yang keluar melalui urin pada sindrom nefroik anak ${ }^{7}$

\begin{tabular}{lll}
\hline Protein/substansia & $\begin{array}{l}\text { Berat molekul } \\
\text { (Dalton) }\end{array}$ & Keterangan \\
\hline Albumin & 69.000 & Protein utama dalam plasma \\
Transferin & 80.000 & Transport besi dalam plasma \\
Soluble transferrin receptor & 74.000 & Kadarnya dalam plasma meningkat pada defisiensi besi \\
Seruloplasmin & 132.000 & Transporter tembaga dalam plasma \\
Transkobalamin I & 120.000 & Mengikat vitamin B12 dalam plasma \\
Traskobalamin II & 36.000 & Transportasi vitamin B12 dalam plasma \\
Vitamin B12 & 1.355 & Mikronutrien non protein \\
Eritropoietin & 30.400 & Penting untuk eritropoiesis \\
Imunoglobulin G & 150.000 & Imunoglobulin paling kecil \\
Retinol binding protein & 21.000 & Transportasi vitamin A dari hati ke jaringan perifer \\
Beta-2 microglobulin & 11.000 & Protein berat molekul rendah \\
Alpha-1 microglobulin & 26.000 & Protein berat molekul rendah \\
\hline
\end{tabular}


Sudung O. Pardede: Anemia pada sindrom nefrotik anak: patogenesis dan tata laksana

\section{Peran besi dan eritropoietin dalam eritropoiesis}

Besi mempunyai peran yang sangat penting dalam eritropoiesis, dan kekurangan besi akan menyebabkan anemia defisiensi besi. ${ }^{7,19,20}$ Dalam tubuh orang dewasa normal, terdapat rata-rata 3-4 gram besi, namun hanya $2-4 \mathrm{mg}$ terdapat dalam plasma, dan sebagian besar terikat dengan protein transport yaitu transferin. Pada orang dewasa normal, sebagian besar sumber besi dalam proses eritropoiesis (15-25 $\mathrm{mg}$ /hari) berasal dari eritrosit tua yang mengalami re-cycling oleh sel makrofag, sedangkan kontribusi besi yang berasal dari absorbsi saluran cerna relatif kecil. ${ }^{7}$ Besi dalam tubuh terutama berasal dari absorbsi enterosit dan organ utama yang menyimpan besi dalam tubuh adalah hati dan limpa, sedangkan besi yang disimpan dalam makrofag ada dalam bentuk ferritin. Besi dilepaskan dari sel penyimpan besi ke dalam plasma melalui eksporter yang disebut dengan feroportin, yaitu protein transmembran yang terdapat di permukaan sel penyimpan besi. Transportasi besi terutama diatur oleh hepsidin, yaitu peptida dengan berat molekul $2,5 \mathrm{kDa}$ yang mengandung 25 asam amino. Hepsidin disintesis dalam hepatosit dan disekresi ke dalam plasma. Hepsidin disekresi secara bebas dan diekskresi oleh ginjal. Hepsidin mengatur homeostasis sistemik besi dengan cara internalisasi dan degradasi feroportin, yang akan menghambat absorbsi besi dalam diet di usus halus, re-cycling besi dari eritrosit tua oleh makrofag, dan mobilisasi besi dari cadangan hati. ${ }^{7,21}$

Transport besi terjadi melalui sel mukosa usus halus bagian atas oleh protein transferin plasma. Transferin adalah glikoprotein yang sangat penting untuk transport besi dari tempat absorbsi ke tempat penyimpanan (storage) untuk digunakan tubuh. Sintesis transferin terjadi terutama dalam hati yang juga merupakan tempat penyimpanan besi. Pada sindrom nefrotik, terjadi kehilangan protein yang masif yang menyebabkan penurunan kadar transferin plasma dan penurunan kadar besi plasma, sehingga pada sindrom nefrotik biasanya terdapat anemia mikrostik hipokrom. ${ }^{22,23}$

Besi yang terikat transferin ditransportasikan ke dalam sumsum tulang dan kemudian ditangkap oleh prekursor eritrosit yang difasilitasi oleh eritropoietin. Eritropoietin adalah glikoprotein yang diproduksi terutama oleh fibroblast peritubular ginjal, namun pada masa janin dan neonatus, eritropoietin terutama diproduksi oleh hepatosit. Eritropoietin yang bersirkulasi dalam plasma (waktu paruh 6-8 jam) terikat ke reseptor dengan afinitas tinggi yang terdapat pada permukaan sel progenitor eritroid di sumsum tulang. Ikatan ini akan menyebabkan pematangan sel prekursor menjadi eritrosit. ${ }^{7}$

\section{Mekanisme terjadinya anemia pada sindrom nefrotik}

Mekanisme terjadinya anemia pada penyakit ginjal kronik sudah diketahui, namun penyebab anemia pada sindrom nefrotik dengan fungsi ginjal yang normal masih belum diketahui sepenuhnya. Anemia pada sindrom nefrotik dapat disebabkan beberapa mekanisme yaitu perubahan homeostasis besi dan transferin, pengeluaran eritropoietin melalui urin, peran obat dan logam, dan defisiensi vitamin B12.

Anemia pada sindrom nefrotik biasanya berupa anemia mikrositk hipokrom yang umumnya disebabkan defisiensi besi tetapi resisten terhadap terapi besi karena proses hilangnya transferin dalam jumlah banyak melalui urin. Kehilangan erItropoietin melalui urin akan menyebabkan anemia defisiensi eritropoietin dan transferinuria, yang meningkatkan katabolisme transferin yang akan menginduksi hipotranferinemia dan anemia defisiensi besi. ${ }^{4}$

Rabeea dkk melakukan penelitian terhadap 50 anak dengan sindrom nefrotik, yang dibagi menjadi dua kelompok, yakni 25 anak dengan sindrom nefrotik aktif dan 25 dengan keadaan remisi, yang dibagi sesuai dengan umur berpasangan, dan dilakukan pemeriksaan laboratorium. Hasil penelitian menunjukkan bahwa kadar hemoglobin, mean corpuscular volume, dan hematokrit pada sindrom nefrotik keadaan aktif lebih rendah secara bermakna dibandingkan dengan sindrom nefrotik dalam keadaan remisi. Demikian juga dengan kadar besi serum, ferritin dan transferin serum lebih rendah secara bermakna pada sindrom nefrotik keadaan aktif dibandingkan dengan dalam keadaan remisi. Rerata kadar transferin urin lebih tinggi secara bermakna pada sindrom nefrotik keadaan aktif dibandingkan dengan dalam keadaan remisi. Ekskresi transferin yang masif melalu urin akan menyebabkan kadar transferin plasma menurun yang mengakibatkan penurunan kadar besi plasma. Keadaan ini mengakibatkan anemia mikrositik hipokrom yang resisten terhadap pemberian besi. Pengeluaran 
transferin urin merupakan parameter untuk prediksi dini terhadap anemia defisiensi besi pada anak dengan sindrom nefrotik. ${ }^{22,23}$

\section{Pengeluaran besi dan transferin}

Pada sindrom nefrotik terdapat anemia defisiensi besi akibat meningkatnya pengeluaran besi dan transferin melalui urin. Besi yang keluar melalui urin terikat dengan transferin dan tetap keluar meskipun urin bersifat alkali. Lama pasien menderita sindrom nefrotik merupakan faktor penting dalam terjadinya anemia defisiensi besi pada sindrom nefrotik. Pengeluaran transferin melalui urin turut berperan terhadap terjadinya anemia pada sindrom nefrotik, dan pengeluaran transferin melalui urin diikuti dengan penurunan kadar transferin plasma., ${ }^{7,24}$ Pada keadaan penurunan kadar transferin plasma, tubuh akan memberikan respon dengan meningkatkan sintesis transferin di hati. Namun respon sintesis hati ini tidak mampu menggantikan kehilangan transferin melalui urin Normalisasi kadar transferin plasma dapat dilakukan dengan mengatasi proteinuria. Pada anak dengan sindrom nefrotik sensitif steroid yang disertai meningkatnya pengeluaran trasferin melalui urin terdapat peningkatan soluble transferrin receptor, sama seperti yang terjadi pada anemia defisiensi besi. Namun peran soluble transferrin receptor dalam mencegah anemia defisiensi besi pada sindrom nefrotik belum jelas. dan masih memerlukan penelitian. ${ }^{7}$

Lu dkk ${ }^{5}$ melaporkan 37 anak dengan sindrom nefrotik idiopatik dan 35 anak sehat (sebagai kontrol) yang berpasangan berdasarkan umur dan jenis kelamin. Dilakukan pemeriksaan laboratorium besi serum, ferritin, transferin, total iron-binding capacity (TIBC), saturasi transferin, dan parameter hematologi seperti hemoglobin, mean corpuscular volume (MCV), mean corpuscular hemoglobin $(M C H)]$, transferin dan eritropoietin urin pada anak sindrom nefrotik idiopatik sebelum terapi dan saat remisi dan pada anak sehat. Hasil laboratorium menunjukkan besi serum $(18,8 \pm 3,8)$ $\mu \mathrm{mol} / \mathrm{L}$ pada sindrom nefrotik idiopatik sebelum terapi lebih rendah secara bermakna dibandingkan anak normal $(22,2 \pm 3,8) \quad \mu \mathrm{mol} / \mathrm{L}$ dan pada saat keadaan remisi $(21,0 \pm 3,5) \mu \mathrm{mol} / \mathrm{L}$ (semua dengan $\mathrm{p}<001)$. Kadar transferin serum pada sindrom nefrotik idiopatik sebelum terapi $(1,9 \pm 0,3) \mathrm{g} / \mathrm{L}$ lebih rendah dibandingkan pada anak sehat $(3,1 \pm 0,5) \mathrm{g} / \mathrm{L}$ dan pada saat remisi, $(2,9 \pm 0,6) \mathrm{g} / \mathrm{L}$ (semua dengan $\mathrm{p}<$ 0,01). Keadaan sebaliknya terdapat pada TIBC serum dan saturasi transferin yang terlihat lebih tinggi secara bermakna pada sindrom nefrotik idiopatik sebelum terapi dibandingkan dengan anak sehat $(\mathrm{TIBC}(56,4 \pm 9,2) \mu \mathrm{mol} / \mathrm{L}$ vs. $(50,7 \pm 6,8) \mu \mathrm{mol} /$ $\mathrm{L}, \mathrm{p}<0,01)$; saturasi transferin $(55,7 \pm 9,2) \%$ vs. $(46,4 \pm 8,2) \%, \mathrm{p}<0,01]$ dan lebih tinggi dibandingkan pada saat remisi. $(51,9 \pm 7,7) \mu \mathrm{mol} / \mathrm{L}$ dan $(47,4 \pm 13,3)$ $\mu \mathrm{mol} / \mathrm{L}$ (semua dengan $\mathrm{p}<0,01$ ). Transferin serum berkorelasi positif dengan albumin serum $(r=0,609$, $\mathrm{p}<0,01)$ dan berkorelasi negatif dengan transferin urin $(\mathrm{r}=-0,550, \mathrm{p}<0,01)$ pada sindrom nefrotik idiopatik sebelum terapi. Hasil penelitian ini melaporkan bahwa besi serum, transferin dan kadar eritropoietin menurun pada pasien sindrom nefrotik idiopatik, yang berhubungan dengan kehilangan melalui urin. ${ }^{5}$

\section{Pengeluaran eritropoietin melalui urin}

Defisiensi eritropoietin perlu dipertimbangkan sebagai salah satu faktor yang menyebabkan anemia pada sindrom nefrotik. Eritropoietin merupakan protein dengan berat molekul $30,4 \mathrm{kDa}$, jauh lebih rendah dibandingkan albumin, dan pada sindrom nefrotik terjadi pengeluaran eritropoietin melalui urin. Umumnya, kadar eritropoietin lebih rendah pada sindrom nefrotik dibandingkan dengan anak tanpa kelainan ginjal. Kadar eritropoietin lebih tinggi pada anak dengan sindrom nefrotik disertai anemia dibandingkan dengan tanpa anemia. ${ }^{7}$

Feinstein $\mathrm{dkk}^{6}$ (2001) melakukan penelitian untuk mengetahui peran eritropoietin terhadap terjadinya anemia pada anak penderita sindrom nefrotik dengan fungsi ginjal normal. Mereka memeriksa kadar eritropoietin, status besi, dan kadar vitamin B12 pada 32 orang anak sindrom nefrotik, yang terdiri atas 19 anak dengan anemia dan 13 orang tanpa anemia. Hasilnya menunjukkan bahwa kadar besi dan ferritin lebih rendah secara bermakna pada subjek dengan anemia dibandingkan dengan subjek tanpa anemia. Eritropoietin lebih tinggi pada sindrom nefrotik dengan anemia dibandingkan dengan tanpa anemia $(21,6 \pm 3,3$ vs. $5,5 \pm 0,8 \mathrm{IU} / \mathrm{L}$ dengan $\mathrm{p}<0,001)$. Hasil penelitian $\mathrm{Lu} \mathrm{dkk}^{5}$ melaporkan bahwa kadar eritropoietin menurun pada pasien sindrom nefrotik idiopatik yang berhubungan dengan kehilangan melalui urin. 
Sudung O. Pardede: Anemia pada sindrom nefrotik anak: patogenesis dan tata laksana

\section{Defisiensi vitamin B12}

Vitamin B12 atau kobalamin adalah komponen organik non protein yang berperan dalam pembentukan sel darah merah. Vitamin B12 berperan sebagai kofaktor dalam pembentukan asam amino metionin dari homosistein serta pada proses interkonversi methylmalonyl-CoA menjadi succinyl-CoA. Vitamin B12 diabsorbsi dari saluran cerna dalam bentuk vitamin B12-intrinsic factor complex yang kemudian ditransportasikan dalam plasma yang terikat dengan protein transkobalamin. ${ }^{7,25}$ Pada proses absorbsi vitamin B12 dalam saluran cerna terdapat peran cubulin, yaitu protein membran perifer yang berperan sebagai reseptor vitamin B12-intrinsic factor complex. Cubulin juga berperan dalam reabsorsi protein yang difiltrasi ke tubulus proksimal ginjal melalui proses endositosis. Mutasi gen cubulin (CUBN) telah diketahui berperan terhadap terjadinya anemia megaloplastik dan meningkatnya eksresi protein melalui urin. ${ }^{7}$

Hasil penelitian Feinstein $\mathrm{dkk}^{7}$ menunjukkan bahwa kadar vitamin B12 lebih rendah secara bermakna pada sindrom nefrotik dengan anemia dibandingkan dengan subjek tanpa anemia. ${ }^{6}$ Defisiensi vitamin B12 akan menyebabkan gangguan sintesis deoxy-ribonucleic acid (DNA) serta kematian prematur sel hematopoietik sebelum mengalami maturasi yang menyebabkan anemia megaloplastik. Kehilangan signifikan transkobalamin dan vitamin B12 melalui urin pada anak dengan sindrom nefrotik akan mengakibatkan penurunan kadar vitamin B12 plasma.

\section{Peran logam dan obat}

Logam dan beberapa obat terkait dengan sindrom nefrotik dapat menyebabkan anemia. Tembaga (copper) berperan dalam eritropoiesis dan berfungsi sebagai kofaktor pada berbagai reaksi enzimatik tubuh. Defisiensi tembaga dapat menyebabkan anemia maupun kelainan hematologis lainnya. Dalam mitokondria, tembaga berperan sebagai kofaktor tehadap cytochromec-oxydase, yaitu enzim terminal pada rantai respirasi mitokondria. Defisiensi tembaga menyebabkan pembesaran mitokondria dalam sel eritropoietik, yang mengakibatakan diferensiasi eritropoietik yang tidak efektif dan anemia mikrositik hipokrom. Seruloplasmin adalah protein karier tembaga dalam plasma. Pada sindrom nefrotik, kehilangan seruloplasmin melalui urin dapat menyebabkan defisiensi tembaga yang mengakibatkan anemia dan suplementasi tembaga dapat memperbaiki anemia. ${ }^{7}$

Obat angiotensin converting enzyme inhibitors (ACEIs) merupakan obat yang sering digunakan pada anak dengan sindrom nefrotik, baik sebagai antihipertensi maupun sebagai antiproteinuria. Pada pasien transplantasi ginjal, pemberian ACEI, dapat menyebabkan anemia, sehingga obat ini digunakan sebagai terapi eritrositosis. ACEI mempunyai efek inhibisi pada eritropoiesis dengan menurunkan kadar eritropoietin sirkulasi yang dapat menyebabkan eksaserbasi anemia. ${ }^{7}$

Obat imunosupresan mikofenolat mofetil mempunyai efek antiproliferatif dan pemberian obat ini dapat mengakibatkan anemia berat akibat penekanan sumsum tulang. ${ }^{7}$

\section{Tata laksana}

Untuk evaluasi anemia pada sindrom nefrotik, perlu dilakukan pemeriksaan darah tepi lengkap, apusan darah perifer, retikulosit, besi serum, total iron binding capacity, saturasi transferin, serta kadar transferin dan ferritin. Mean corpuscular volume yang rendah menggambarkan defisiensi b esi disertai kadar besi, ferritin dan saturasi transferin yang rendah. ${ }^{7,19,20}$ Mean corpuscular volume yang meningkat menggambarkan anemia makrositik yang biasanya disebabkan anemia defisiensi vitamin B12 dan asam folat. Pada sindrom nefrotik dengan anemia yang tidak responsif terhadap terapi suplementasi besi, perlu dipertimbangkan pemeriksaan kadar eritropoietin plasma dan urin dengan cara radioimmunoassay atau enzyme-linked assay (ELISA). Pada anemia persisten setelah terapi besi dan eritropoietin diperlukan evaluasi lebih lanjut untuk mencari kemungkinan defisiensi tembaga atau vitamin B12. Pemeriksaan kobalamin plasma merupakan pemeriksaan untuk mengetahui defisiensi vitamin B12. Pada kasus yang resisten terhadap terapi, perlu dipertimbangkan kemungkinan defisiensi tembaga atau seruloplasmin dengan memeriksa kadar tembaga plasma. ${ }^{7,25}$

Keberhasilan terapi anemia pada sindrom nefrotik bergantung pada penyebab anemia dan tata laksana sindrom nefrotik dengan prednison atau imunosupresan lain. Sindrom nefrotik dengan anemia umumnya resisten terhadap terapi imunosupresan, 
sedangkan sindrom nefrotik tanpa anemia umumnya sensitif terhadap imunosupresan. ${ }^{7}$

Anemia defisiensi besi diterapi dengan suplementasi besi. Peningkatan hemoglobin setelah 2 minggu pemberian preparat besi merupakan prediktor terapi yang baik sebagai respon terhadap terapi besi per oral. ${ }^{7,20}$

Pada sindrom nefrotik persisten, perlu dipertimbangkan pemberian eritropoietin pada pasien dengan kadar eritropoietin normal atau rendah karena adanya proteinuria masif. Pemberian eritropoietin disertai dengan suplementasi besi pada pasien sindrom nefrotik dengan anemia akan meningkatkan kadar hemoglobin secara bermakna tanpa efek samping yang berarti, namun mengatasi proteinuria merupakan tata laksana yang ideal untuk mengatasi komplikasi ini. ${ }^{4}$

Untuk terapi defisiensi tembaga, diberikan suplementasi tembaga glukonat. Defisiensi vitamin B12 diterapi dengan multivitamin oral yang mengandung vitamin B12. Pemberian vitamin B12 injeksi subkutan atau intramuskular dapat dipertimbangkan pada anemia berat yang tidak responsif dengan terapi oral. 7,25

Pemeriksaan retikulosit merupakan petanda laboratorium eritropoiesis yang efektif, dan kadarnya akan rendah pada anemia karena defisiensi besi, eritropoietin, vitamin B12, asam folat, dan tembaga. Pemeriksaan retikulosit direkomendasikan sebagai petanda eritropoiesis dan respon terhadap terapi. Pemeriksaan retikulosit 1-2 minggu setelah pemberian obat merupakan indikasi untuk menilai respon terapi inisial. Interval 4 minggu merupakan waktu yang logis untuk evaluasi respon terapi tembaga dan vitamin B12. ${ }^{7}$

\section{Kesimpulan}

Anemia dapat terjadi pada sindrom nefrotik. Meskipun patogenesis anemia pada sindrom nefrotik kompleks dan belum diketahui sepenuhnya, namun umumnya disebabkan defisiensi besi, eritropoietin, vitamin B12, dan asam folat. Pemahaman mengenai mekanisme terjadinya anemia merupakan hal yang sangat penting untuk keberhasilan tata laksana anemia.

\section{Daftar pustaka}

1. Valentini RP, Smoyer WE. Nephrotic syndrome. Dalam: Kher KK, Schnaper HW, Makker SP, penyunting, Clinical Pediatric Nephrology. Edisi kedua. London: Indofarma Health Care; 2007.h.155-94.

2. Lombel RM, Hodson EM, Gipson DS. Treatment of steroidresistant nephrotic syndrome in children: new guidelines from KDIGO. Pediatr Nephrol 2013:28:409-14.

3. Haycock GB. The child with idiopathic nephrotic syndrome. Dalam: Postlethwaite RJ, Webb N, penyunting. Clinical Paediatric Nephrology. Edisi ke-3. New York: Exford University Press; 2003.h.341-66.

4. Park SJ, Shin JL. Complications of nephrotic syndrome. Kor J Pediatr 2011;54:322-8.

5. Lu H, Liu D, Zhang W, Yuan Y, Kuang H, Wang L, dkk. Serum erythropoietin and transferrin in children with idiopathic nephrotic syndrome. Fronitier Med 2008;2:286-9.

6. Feinstein S, Becker-Cohen R, Algur N, Raveh D, Shalev $\mathrm{H}$, Shvil Y, dkk. Erythropoietin deficiency causes anemia in nephrotic children with normal kidney function. Am J Kidney Dis 2001;37:736-42.

7. Iorember F, Aviles D. Anemia in nephrotic syndrome: approach to evaluation and treatment. Pediatr Nephrol 2017;32:1323-30.

8. Shalhoub RJ. Pathogenesis of lipoid nephrosis: a disorder of T-cell function. Lancet 1974;2:556-60.

9. Iharada A, Kaneko K, Tsuji S, Hasui M, Kanda S, Nishiyama $\mathrm{T}$. Increased nitric oxide production by $\mathrm{T}$ - and B-cells in idiopathic nephrotic syndrome. Pediatr Nephrol 2009;24:1033-8.

10. Brenchley PE. Vascular permeability factors in steroid-sensitive nephrotic syndrome and focal segmental glomerulosclerosis. Nephrol Dial Transplant 2003;18 Suppl 6:21-5.

11. Shimoyama $H$, Nakajima M, Naka H, Maruhashi $Y$, Akazawa $\mathrm{H}$, Ueda T, dkk. Up-regulation of interleukin-2 mRNA in children with idiopathic nephrotic syndrome. Pediatr Nephrol 2004;19:1115-21.

12. Araya C, Diaz L, Wasserfall C, Atkinson M, Mu W, Johnson $\mathrm{R}$, dkk. T regulatory cell function in idiopathic minimal lesion nephrotic syndrome. Pediatr Nephrol 2009;24:1691-8.

13. Niaudet P. Steroid-sensitive idiopathic nephrotic syndrome in children. Dalam: Avner ED, Harmon WE, Niaudet P, penyunting. Pediatric Nephrology. Edisi ke-5. Philadelphia: Lippincott Williams \& Wilkins; 2004.h.543-56.

14. van den Berg J, Weening JJ. Role of the immune system in the pathogenesis of idiophatic nephrotic syndrome. Clin Sci (Lond) 2004;107:125-36.

15. Kaneko K. Pathogenesis in childhood idiopathic nephrotic syndrome: an update of patchwork. Current Pediatr Rev 2009;5:56-64.

16. Jalanko H. Pathogenesis of proteinuria: lessons learned from nephrin and podocin. Pediatr Nephrol 2003;18:487-91.

17. Wang Z, Klipfell E, Bennett BJ, Koeth R, Levison BS, Dugar $\mathrm{B}, \mathrm{dkk}$. Gut flora metabolism of phosphatidylcholine promotes 
cardiovascular disease. Nature. 2011;472:57-63.

18. Ito S, Tsutsumi A, Harada T, Inaba A, Fujinaga S, Kamei K Long-term remission of nephrotic syndrome with etanercept for concomitant juvenile idiopathic arthritis. Pediatr Nephrol 2010;25:2175-7.

19. Gunadi D, Lubis B, Rosdiana N. Terapi dan suplementasi besi pada anak. Sari Pediatri 2009;11:207-13.

20. Goddard AF, James MW, McIntyre AS, Scott BB. British Society of Gastroenterology. Guidelines for the management of iron deficiency anaemia. Gut. 2011;60:1309-16.

21. Nemeth E, Ganz T. The role of hepcidin in iron metabolism. Acta Haematol 2009;122:78-86.

22. Rabeea MM, Al-Akkad NM, El-Morsi GZ, Darwish AE.
Evaluation of serum iron and transferrin in children's suffering with idiopathic nephrotic syndrome. Cientific J Pediatr 2019;1:9-16.

23. Rabeea MM, Al-Akkad NM, El-Morsi GZ, Elsayed A. Evaluation of serum iron and transferrin in idiopathic nephrotic syndrome patients attending Al-Hussein Pediatric Nephrology Clinic. Egyptian J Hospital Med 019;74:1036-46.

24. Brown EA, Sampson B, Muller BR, Curtis JR. Urinary iron loss in the nephrotic syndrome- an unusual cause of iron deficiency with a note on urinary copper losses. Postgraduate Med J 1984;60:125-8.

25. Langan RC, Goodbred AJ. Vitamin B12 deficiency: recognition and management. Am Fam Phy 2017;96:385-9. 